\begin{tabular}{c} 
Volume and Issues Obtainable at Center for Sustainability Research and Consultancy \\
Sustainable Business and Society in Emerging Economies \\
ISSN: $2708-2172$ \& (E): $2708-2504$ \\
Volume 3: Issue 1 March 2021 \\
CSRE \\
Journal homepage: $\underline{\text { www.publishing.globalcsrc.org/sbsee }}$ \\
\hline
\end{tabular}

\title{
Firm Specific Capability Organizational Structure and New Product Performance of Fast Moving Consumer Goods Manufacturers in Emerging Economy
}

*Onamusi Abiodun B, Department of Management \& Accounting, Lead City University, Ibadan, Nigeria

Adenekan Tolulope E, Department of Information Management, Lead City University, Ibadan, Nigeria Ojo Elizabeth O, Lead City University, Ibadan, Nigeria

Owolabi Olubukola A, Lead City University, Ibadan, Nigeria

*Corresponding author's email address: abiodunonamusi@gmail.com

\begin{tabular}{l}
\hline ARTICLE DETAILS \\
\hline History \\
Revised format: Feb 2021 \\
Available Online: Mar 2021 \\
\hline
\end{tabular}

Keywords

Firm-Specific Capability, Organizational Structure, New Product Performance, Dynamic Capability Theory, Structural Contingency Theory

\section{JEL Classification}

F23, L25, L66, M31

\begin{abstract}
Purpose: This study was centered on understanding the linkages between internal organizational competencies and performance of new products and the role of organizational structure focusing on Fast Moving Consumer Goods (FMCGs) manufacturers in the SouthWestern States in Nigeria.

Methodology: A survey approach was adopted, and 529 employees of fifteen FMCGs took part in data gathering. A moderated regression analysis was used to test the hypotheses formulated

Findings: The results of the moderated regression analysis established that firm-specific capability significantly enhanced new product performance, and the introduction of a definitive organizational structure increased the established effect firm-specific capability had on new product performance to suggest a significant moderator.

Implications: Management of the FMCGs investigated need to strengthen their commitment to developing critical and dynamic firmspecific capability and understand the relevance of organizational structure appropriateness. The firms should possess the knowledge to deploy ambidextrous firm-specific capability; it would enable the firms to expand and explore market opportunities that facilitate achieving significant new product performance.
\end{abstract}

(C) 2021 The authors, under a Creative Commons AttributionNonCommercial- 4.0

Recommended citation: Abiodun B, O., Tolulope E, A., Elizabeth O, O. \& Olubukola A, O. (2021). Firm Specific Capability Organizational Structure and New Product Performance of Fast Moving Consumer Goods Manufacturers in Emerging Economy. Sustainable Business and Society in Emerging Economies, 3 (1), 1-11.

\section{Introduction}

Intense competition is an attribute of the external business environment in which firms operate. Hence, it is critical that firms consistently offer new (incremental and or radical) products that satisfy the needs of varying customer demands, strengthen their competitiveness, and meet their expected financial return's objective especially in an emerging economy. Academic discussions in the area of Firm-Specific 
Capability (FSC) have investigated how to continually improve the performance of new product through research and development (R\&D) efforts, innovation and inter-departmental collaboration for New Product Performance (NPP), marketing capabilities, knowledge acquisition, and sharing for successful NPD, in different economic settings; developed, emerging market and developing economies (Bendig, Enke, Thieme, \& Brettel, 2018; Chang, Bai, \& Li, 2015; Feng, Huang, \& Avgerinos, 2018; Gumusluoglu \& Acur, 2016; McCann \& Bahl, 2016; Mu, 2015). Nevertheless, a few scholars examined the FSC-NPP linkage (Chang et al., 2015; Feng, Huang, \& Avgerinos, 2018; McCann \& Bahl, 2016; Shinkle \& McCann, 2014; Sok \& O'Cass, 2015; Song \& Chen, 2014; Tsai \& Hsu, 2014; Wei, Yi, \& Guo, 2014). Although, scholars share common thought that NPP is vital for organizations (Shinkle \& Macann, 2014) because it can boost organizational capability to adapt to market dynamics, sustain market share and influence firm competitiveness. Nevertheless, their findings provided a mixed result, which could result from the contextual, methodological differences, and the issues addressed.

In manufacturing organizations, the processes leading to attractive NPP are not entirely an inter-firm activity but one that incorporates the external stakeholder. These include suppliers (Vanpoucke, Vereecke, \& Wetzels, 2014), who offer complementary assets to the firm, Market (Mu, Bao, Sekhon, Qi, \& Love, 2018), and customers (Fidel, Schlesinger, \& Cervera, 2015). The inability to effectively engage these stakeholders, the enormous cost associated with sourcing raw materials, and the harsh operating environment in Nigeria (Sylva, Ofoegbu, \& Akpan, 2016) may have contributed to the poor performance recorded for new product (Pampers's baby dry, Huggies baby essential, Nuric) introduced to the market by Procter \& Gamble, PZ Cusson, and Friesland Campina. As a result, these products have neither gained nor sustained market share. This poor product performance has grave financial consequences, considering the resources invested in developing a new product from ideation to commercialization. To buttress this point, Procter \& Gamble shut down one of their production plants in Lagos State's Agbara industrial estate in 2018, while Pz Cusson announced a cutback on operations in Nigeria in 2019. Furthermore, Kimberly Clark's Huggies' baby essential showed that a low-cost strategy is not for every business because even after adopting the low-cost strategy for its local brand, the company's NPP is below expectations (Nairametrics, 2018; Procter \& Gamble press release July 2018; PZ Cusson press release January 2019). It is imperative to stress that the attendant consequences of the covid-19 pandemic hold severe adverse effects for firms in this category.

Organizations are composed of different functional units; hence, it is vital to have a well-designed Organizational Structure (OS) to align these functional units and set them up to achieve organizational goals (Chen, Li, \& Liu, 2015). Literature has provided evidence of scholarly studies on the FSCorganizational performance linkage (Arasa \& Gideon, 2015; Feng et al., 2018; McCann \& Bahl, 2016; Najafi-Tavani et al., 2018; Ngo, Bucic, Sinha, \& Lu, 2019; Sok \& O'Cass, 2015). However, not much is done to establish the moderating effect of OS in the light of the listed studies. A few scholars related OS with firm adaptability and performance (Adler \& Borys, 1996; Zahra \& Covin, 1995), and Wilden, Gudergan, Nielsen, and Lings (2013) examined the effect of OS in conjunction with the internal organizational process. However, studies that have combined both its ability to adapt to environmental turbulence and enhance internal organizational processes are scarce, presenting a gap worthy of study. Thus, not much is known about how OS moderates the interactions between FSC and NPP of manufacturers of FMCGs in South-Western States, Nigeria. Also, Nwonu, Agbaeze, and Obi-Anike (2017) emphasized that the failure to manage a firm's OS and achieve fit among contingent factors like strategy, structure, and environment produce poor overall organizational performance, and the manufacturers of FMCGs are not excluded. The identified gap limits the broader relevance of specific firm-level competencies link with the performance of a new product and how a definitive system of shared authority and responsibility can enhance the association between FSC and NPP. Based on this discussion, this study addressed the effect of FSC on NPP and whether OS acts as a contingent factor that will enhance the association between FSC and NPP focusing on FMCG industry in South-Western States, Nigeria. 


\section{Literature Review}

\section{Theory and Basis for the Hypotheses}

This study draws on Resource Base-View (RBV), Dynamic Capability Theory (DCT), and the Structural Contingency Theory (SCT) to address the interaction between FSC, NPP, and OS. RBV opines that firms desirous of achieving competitive advantage must possess internal organizational resources to do so (Onamusi, 2020). More so, such internal organizational resources need to be unique, complex to copy, and the firm can use them (Chukwuemeka \& Onuoha, 2018; Fidel, Schlesinger, \& Cervera, 2015; Zhang \& Hartley, 2018). In addition, the DCT perspective suggests only dynamic capabilities; one that enhances a firm's adaptability to environmental changes, absorb information within and externally and innovate its operation to take advantage of market dynamics within changing macro-environment to achieve competitive advantage (Teece, 2014a; Kaur \& Mehta, 2017; Wang, Senaratne, \& Rafiq, 2015).This implies a direct and indirect interaction exist between the ownership of dynamic internalexternal capabilities and superior firm performance (Schilke, Hu, and Helfat, 2018; Kaur \& Mehta, 2017; Lee, Wu, Kuo, \& Li, 2016).

Moreover, FSC such as engaging customers, developing new products, conducting creative marketing survey, and been innovative are not static competencies which mean as environmental factors changes and market demands become less predictable, firms can count on its dynamic FSC to cope with the changes and achieve better performance than firms with static capability. Overall, the central supposition of the RBV and DCT provides the theoretical underpinnings for the first hypothesis in this study. Hence, the study hypothesized that: (H1) the ownership of FSC will significantly enhance NPP. Also, the Structural Contingency Theory (SCT) advocates that OS appropriateness remains a contingent factor that can enhance firm competencies to deliver efficient value. Hence this study proposes that $(\mathrm{H} 2)$ the association between FSC and NPP will significantly be enhanced by OS.

\section{Firm-Specific Capability and New Product Performance}

In an attempt to establish which firm capabilities, influence NPP, the preliminary result in Mu (2015) showed that both Marketing Capability (MC) and NPP are strongly and positively correlated. However, further analysis revealed that the ability of a firm's MC to contribute significantly to NPP is contingent on firms that have ambidextrous competence. That is a firm competent in combining two extreme product innovation activities: exploitation and exploration. Unlike $\mathrm{Mu}$ (2015), who examined the US and Chinese tech firms, Azubuike (2013) focused on manufacturing companies in Nigeria, and the findings posit that technological innovation competencies significantly correlates with NPP and profitability. Although the research context in Azubuike (2013) and Mu (2015) differ, underscoring their findings show support for the argument put forward by the proponents of RBV; organization capabilities (FSC) drive performance.

The findings in Talaja's (2013) study aligned with Azubuike's (2013) with few additions. The author investigated the performance-effect of foreign firms' innovation capability, and it confirmed that firms that possess innovative proficiency achieve better performance, irrespective of the company's size. Further analysis showed that foreign firms had more capability to develop new products and consequently reap better NPP. In an attempt to substantiate how specific internal organization's contingencies, influence NPP, Wei, Yi, and Guo's (2014) result suggested that NPP is attributed to organization learning flexibility and innovation exploration capacity in NPD. However, unlike Wei et al. (2014) that focused on learning and innovation, Kim et al. (2016) sort to establish a link between two firm-specific capabilities; marketing proficiency and technological asset that drives NPP of Korean firms. The study suggested that technological resources (proxy to innovation capability) enhance marketing capability to influence NPP. Specifically, the positive association between MC and NPP was explained by possessing technological resources such as dynamic and embedded technology assets.

Also, Lee, Lee, and Garrett (2017) decided to prove the collaboration effect of innovation on the organizational performance of firms in Korea. The result confirmed that through exploitation and 
exploration behavior, innovation capability dimensions such as product and process influenced firm performance. These findings echo the submission of scholars such as Azubuike (2013) and Foroudi, Jin, Gupta, Melewar, and Foroudi (2016) and Ukpabio, Oyebisi, and Siyanbola (2017) on the significant performance-effect of innovation capability. By implication, Lee et al. (2017) encourages firms in their commitment to innovate to embrace exploiting their present market in a bid to penetrate the market and improve on products initially offered, and to explore the possibilities of offering an entirely new product to the market. According to the study, the innovation activities will guarantee superior market and financial performance if this is done.

Focusing on another FSC variable different from Lee et al. (2017) and Ukpabio et al. (2017), Dirisu et al. (2013), was interested in determining what NPD feature drive NNP. The findings revealed that NPD features, such as uniqueness and quality, drive NPP. Contrasting to Dirisu et al. (2013), Ateke and Iruka (2015) were more interested in NPD activities that can influence NPP but not the NPD features. The scholar found that involving the customers in the NPD activities (co-creation activities) is significant for NPP. The study revealed that customer involvement management and NPP are strongly and positively related. This stressed that when customers are involved in the co-creation activities to produce a new product, their expectations as per product features and quality are captured, reducing the potential for NPD failures. To buttress the submission of Ateke and Iruka (2015) and Dirisu, Iyiola, and Ibidunni (2013), through co-creation activities, customers enjoy a positive brand experience, which drives customer satisfaction and subsequently improves NPP. Several scholars have substantiated this point of view with studies in a different research context, for example, in the aviation industry, hotel and banking industry, among retailer and automobile industry respectively (Chahal \& Dutta, 2014; Ha \& Perks, 2005; Khan, Garg, \& Rahman, 2015; Kim, Chua, Lee, Boo, \& Han, 2016; Lin, 2015; Şahin, Turhan \& Zehir, 2013).

From an outside-in marketing capability, Ateke and Iruka (2015) focused on one dimension of marketing capability: customer involvement; however, Mu et al. (2018) considered all the dimensions of marketing capability to position its relevance to organizational performance. The study revealed that proficiency in market sensing, partner-linking, customer engagement, selling, communication, and market implementation (dimensions of outside-in marketing capability) guarantees superior performance measured as profitability, market share, and customer satisfaction. Moreover, since all the performance measures used by Mu et al. (2018) are the standard measure for NPP, it would not be out of place to say that Outside-in marketing capability significantly explains the performance of a new product.

This finding draws strength from the customer-focus-driven perspective, highlighting the need to incorporate customer/market realities into productive activities needed for the market, hence avoiding the potential failure of NPD activities and the massive waste of resources. As such, it becomes imperative for firms to acquire information from external sources. Scholars suggest that such information is obtainable from different sources, which include informal business discussions, rival competitiveness, collaborative business efforts, market survey, customer interactions, and capabilities to influence government (Acur, Kandemir, \& Boer, 2013; Chen, Tribbitt, Yang, \& Li, 2017; Feng et al., 2018; Fidel et al., 2015; McCann \& Bahl, 2016; Mu et al., 2018; Najafi-Tavani et al., 2018). In all, firms must prioritize developing proficiency from outside-in such that their inside-out capabilities can accomplish superior performance.

On the contrary, it is difficult to fault the usefulness of firm-specific capabilities like customer engagement and innovation capability, particularly regarding their contribution towards NPP. This is because several authors, as discussed earlier, had found that these capabilities improve NPP significantly; however, some scholars have expressed a contrasting submission. For example, Fang (2008) posited that involving customers in a co-creation function may reduce production efficiency and increase product timeliness to the market. In the same vein, Cheng and Krumwiede (2012) and Gustafsson, Kristensson, and Witell (2012) argued that customer involvement does not benefit all NPD. 
Implying that customer participation benefits mostly incremental new product and its performance; however, it is ineffective in time of a radically new product.

Furthermore, Beckers, Van-Doorn, and Verhoef (2017) found a company's shareholders reacting negatively when it initiated customer involvement activities for the fear that it backfires. Besides, Ngo and O'Cass (2012) queried the direct performance effect of customer engagement capability, suggesting that this capability is a contingent factor through which innovation capability can bring business success. Focusing on innovation capability, Idowu (2013) found no relationship between firm innovativeness and financial performance. Similar to Idowu's (2013) finding was Namusonge, Muturi, and Olaniran's (2016) study. Namusonge et al. (2016) found that innovation-financial performance linkage firms trading with the Nigeria stock exchange were negatively correlated.

\section{Moderating Role of Organisational Structure}

The moderating effect of OS on the relationship between FSC and NPP suggests that not much has been done in this direction. The few scholars (Zahra \& Covin, 1995) that did relate OS with firm adaptability and performance, while Wilden et al. (2013) examined the effect of OS in conjunction with the internal organizational process, however, studies that combined both its ability to adapt to environmental turbulence and enhance internal organizational process are sparse. Thus, the need for a theory that can substantiate a possible interaction.

Many scholars in management research have supported and generally applied the notion that no tactic is comprehensively superior; that is, the performance effect of a strategy is context-specific. They arrived at this submission primarily by adopting the contingency perspective (Nwonu et al., 2017; Oliveira et al., 2018; Titus \& Anderson, 2018; Sayilar, 2016), established within the interaction perspective. As noted by Schoonhoven (1981, p. 351), "When contingency theorists assert that there is a relationship between two variables ... which predicts a third variable... they are stating that an interaction exists between the first two variables", hence accentuating the attractiveness of the interaction perception in organizational studies.

The moderation perspective suggests that the independent variable (FSC) effect on the dependent variable (NPP) is a condition on a third variable (OS), defined as the moderator. In line with this position advanced by the structural contingency theory, which addresses fit as a moderator, this study posits that the fit between OSs as a contingent factor is a prerequisite for high organizational performance. OS generates precise effect relationships that produce improved efficiency and overall performance (Sayilar, 2016). By implication organization, structural fit produces better performance, but organizational performance becomes poor when it fails to achieve a structural fit (Sayilar, 2016).

This study assumes (given the argument of SCT) that the decision for firms to harness inter-firm resources (FSs) for success (NPP) is a herculean task one in which OS can help to facilitate. This line of thought was corroborated by Feng-Jyh and Ching-Wei (2019); according to the Scholars, OS appropriateness is critical to how firms efficiently run their operations (Feng-Jyh \& Ching-Wei, 2019). Hence, stressing the relevance of OS in helping the organization achieve set goals by aligning the internal organization's activities with external contingencies.

\section{Methodology}

The cross-sectional approach to survey design offers this study the ability to collect data from a sampling unit once. From a population of 12,712 employees engaged with fifteen FMCG manufacturers in categories such as food \& Beverage, Sweet \& Biscuit, Baby-care products, and household detergents, 378 using research advisor was computed. We added 151 (40\% of 378), making 521 to ensure that responses obtained from questionnaire administration would not be lower than the optimum sample size of 378. The employees who form the unit of analysis were management-level employees. Data were collected by administering an adapted questionnaire (Bendig et al., 2019; Kadic-Maglajlic et al., 2018) 
with response options ranging from strongly agree to disagree strongly. After eight weeks of questionnaire administration, 452 questionnaires were considered adequately filled, representing a response rate of $85.4 \%$.

In this study, FSC, NPP, and OS are the independent, dependent, and moderating variables, respectively. FSC reflects the extent to which an organization possesses core and unique capabilities and assets (tangible and intangible) which are developed over time, across functional areas whose efficient utilization enables a firm to achieve competitive advantage; more so, its continued improvement ensures the sustenance of the firm's competitive advantage. Hence, the firm-specific capabilities in this study are measured by customer engagement as defined by Anning-Dorson et al. (2018), new product development as defined by $\mathrm{Mu}$ et al. (2017), marketing capability as defined by $\mathrm{Mu}$ et al. (2018), and innovation capability according to Foroudi et al. (2016) definition.

NPP reflects the extent to which a firm's new product developed increases the market presence and success rate, acquire new and maintains existing customers, and can be produced quickly. They were measured using a Likert-type scale by scholars (Bendig et al., 2019; Kadic-Maglajlic et al., 2018). According to Cummings and Worley (2015), the OS reflects the extent to which a uthority and responsibility are defined within a formal system. This study follows a similar approach established by these scholars to measure these variables and use a Likert-type scale to collect the data. In addition, the study adopted the Moderated Regression Analysis (MRA) to determine the moderating effect of OS on the association between FSC and NPP of FMCG manufacturers in the South-Western States in Nigeria.

\section{Analysis and Result}

This study must establish that the data collection instrument is valid and reliable. Hence, we conducted a validity and reliability test to ascertain that. Through principal component factor analysis and using the varimax extraction method, only factor loading of 0.7 and above was considered and used to compute each variable's AVE and CR results. Also, the internal consistency for using Cronbach's alpha coefficient was conducted for all the variables, respectively. The result in Table 4.1 shows that the AVE, $\mathrm{CR}$, and CA had values above the acceptable benchmark of $0.5,0.7$, and 0.7 , respectively.

Table 4.1: Validity and Reliability Result

\begin{tabular}{llccc}
\hline Variables & Measures & CA & CR & AVE \\
\hline Independent & FSC: & & & \\
& Marketing capability & 0.78 & 0.86 & 0.60 \\
& New product development & 0.82 & 0.84 & 0.58 \\
& Customer engagement & 0.77 & 0.82 & 0.54 \\
& Inovation capability & 0.82 & 0.86 & 0.62 \\
Dependent & NPP & 0.89 & 0.83 & 0.71 \\
Moderator & Organisational structure & 0.81 & 0.88 & 0.57 \\
\hline
\end{tabular}

Source: Authors' compilation using SPSS V24 (2021)

Table 4.2: Result of the Moderated Regression analysis

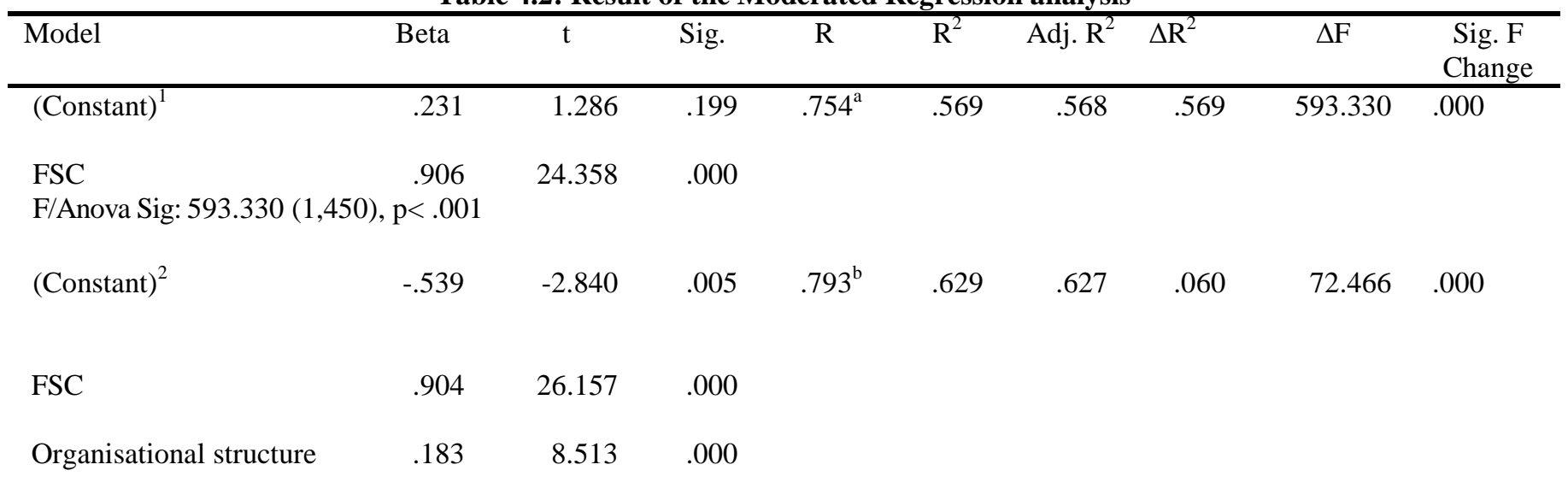


F/Anova Sig: $380.013(2,449), \mathrm{p}<.001$

\begin{tabular}{|c|c|c|c|c|c|c|c|c|}
\hline$(\text { Constant })^{3}$ & -2.986 & -6.171 & .000 & $.807^{\mathrm{c}}$ & .652 & .650 & .023 & 29.899 \\
\hline $\begin{array}{l}\text { Firm-specific } \\
\text { capability }\end{array}$ & 1.397 & 14.529 & .000 & & & & & \\
\hline Organisational structure & .883 & 6.805 & .000 & & & & & \\
\hline $\mathrm{FSC} * \mathrm{OS}$ & -.142 & -5.468 & .000 & & & & & \\
\hline
\end{tabular}

a. Predictors: (Constant), FSC b. Predictors: FSC, OS c. Predictors: FSC, OS, FSC*OS

d. Dependent Variable: NPP

Source: Authors' compilation using SPSS V24 (2021)

Table 4.2 above depicts the MRA for the moderating effect of OS on the relationship between FSC and NPP. The result in model one shows that FSC is a significant contributor to NPP given a $56.9 \%$ variability in NPP attributed to FSC $(\mathrm{R} 2=0.569, \mathrm{~F}(1,450) 593.330, \mathrm{p}<.001)$. Model two established that FSC and OS jointly influence $62.7 \%$ of the changes NPP (Adj. R2 = 0.627, F(2,449)380.013, p=.000). In the last model, therefore, the interaction term of FSC*OS was obtained and considered in the model. The result shows that the introduction of OS improves the relationship between FSC and NPP, given the $2.3 \%$ increase in $\mathrm{R} 2(\Delta \mathrm{R} 2=0.023, \mathrm{p}=0.000)$ experienced in NPP. This finding reinforces the contingent perspective that OS significantly moderates the link between FSC and NPP.

\section{Discussion Conclusion and Recommendation}

The possession of internal organizational capabilities conceptualized as FSCs are considered sustainable elements that drive firm performance (Abiodun, 2017; Lee et al., 2017; Mu, 2015; Tuan, Nhan, Giang, \& Ngoc, 2016; Ukpabio et al., 2017). This finding aligns with the submission of Onamusi (2020), who considered FSC to be the core and unique organizational capabilities and assets (tangible and intangible) developed over time, across functional areas whose efficient utilization enables a firm to achieve superior performance; more so it continued improvement ensure the sustenance of the firm's competitive advantage.

In addition, the findings of this study have support in the empirical literature. For instance, Mu (2015) posited that both NPD and NPP are strongly and positively correlated. Although the research context in Azubuike (2013) and $\mathrm{Mu}$ (2015) differ, underscoring their findings supports the argument put forward by the proponents of RBV; organization capabilities drive performance. The findings in Talaja's (2013) study aligned with Azubuike's (2013). The author indicated that foreign firms had the superior capability to develop new products and consequently reap better NPP.

Similarly, Wei, Yi, and Guo (2014) corroborated Azubuike's (2013) submission that NPP is attributed to NPD organization learning flexibility and innovation exploration capacity. Lee et al. (2017), Ukpabio et al. (2017), and Dirisu et al. (2013), all revealed that the development of a new product with unique features and quality improves the success recorded with regards to such new product. Thus, from the theoretical standpoint, the RBV is strengthened. The RBV, an inside-out perspective, emphasizes that for a firm to achieve superior performance, such firms must own internal organizational knowledge, skill, and ability that are incredibly unique.

The results of hierarchical regression analysis (also MRA) for the moderating effect of OS on the association between FSC and NPP show a significant moderation effect on the association. Scholars have posited that OS is a precondition for attaining an organizational goal. According to Feng-Jyh and Ching-Wei (2019), a suitable OS is necessary for companies to effectively and efficiently manage its activities. Feng-Jyh and Ching-Wei (2019) corroborate Gurianova and Mechtcheriakova (2015), who suggested that OS is a construct that assists with effective decision-making. 
The significant contribution to knowledge that this study offers is evident in the gap is addressed and that it offers relevance for FMCG manufacturers in terms of critical firm-level competencies that can be developed and deployed to aid NPP. More so, providing relevance for having a definitive OS that spells out responsibilities, defines authority, and aligns the organization with its strategy to stay competitive in an environment characterized by erratic customer demand, intense competitive rivalry, and inconsistent government policy in emerging economies. Also, the empirical results add to current literature in FSC and boost the significance of OS. Finally, in terms of theoretical contribution, this study aligns with underlining narratives of the RBV, DCT, and the CT, providing further support for the assumptions of these theories.

The study concludes that FSC affects NPP; OS moderates the interaction between FSC and NPP. Based on these findings, this study recommends that firms strengthen their commitment to developing critical and dynamic FSC. These capabilities have been documented in the literature and supported by the finding of this study to influence firm performance. Also, management must possess the knowledge to deploy the ambidextrous FSC to enable the firms to expand and explore market opportunities that facilitate achieving superior performance in a new product. Lastly, OS appropriateness is key to facilitating operational efficiency in NPP.

\section{References}

Abiodun, T. S. (2017). An examination of the relationships between different types of innovation and firm performance and the mediating effect of radical and incremental Innovations on these relationships. International Journal of Innovation and Economic Development, 3(1), 38-58.

Acur, N., Kandemir, D., \& Boer, H. (2013). Strategic alignment and new product development: Drivers and performance effects. Journal of Product Innovation Management, 29(2), 304-318.

Adler, P. S., \& Borys, B. (1996). Two types of bureaucracy: Enabling and coercive. Administrative Science Quarterly, 41(1), 61-74.

Anning-Dorson, T. (2018). Customer involvement capability and service firm performance: The mediating role of innovation. Journal of Business Research, 86(4), 269-280.

Anning-Dorson, T. (2018). Innovation and competitive advantage creation. International Marketing Review, 35(4), 580-600.

Arasa. R., \& Gideon, L. N. (2015). The influence of international market entry strategies on firm financial performance: A study of the manufacturing multinationals in Kenya. International Journal of Economics, Commerce and Management United Kingdom, 3(9), 332-349.

Asikhia, O. U., \& Makinde, G. O., \& Onamusi, A. B. (2020). Marketing capability and firm performance: Mediating role of new product development and management innovation. The International Journal of Business \& Management, 8(2), 69-77.

Ateke, B. W., \& Iruka, C. H. (2015). Investigating the relationship between customer involvement management and marketing performance in the manufacturing industry. International Journal of Research in Business Studies and Management, 2(9), 22-34.

Azubuike, V. M. U. (2013). Technological innovation capability and firm's performance in new product development. Communications of the IIMA, 13(1), 41-570.

Beckers, S. F., Van-Doorn, J., \& Verhoef, P. C. (2017). Good, better, engaged? The effect of companyinitiated customer engagement behaviour on shareholder value. Journal of the Academy of Marketing Science, 46(3), 366-383.

Bendig, D., Enke, S., Thieme, N., \& Brettel, M. (2018). Performance implications of cross-functional coopetition in new product development: The mediating role of organisational learning. Industrial Marketing Management, 18(4), 66-80.

Chahal, H., \& Dutta, K. (2014). Measurement and impact of customer experience in banking sector. Decision, 42(1), 57-70.

Chang, J., Bai, X., \& Li, J. J. (2015). The influence of leadership on product and process innovations in China: The contingent role of knowledge acquisition capability. Industrial Marketing Management, 50(2), 18-29. 
Chen, T., Tribbitt, M. A., Yang, Y., \& Li, X. (2017). Does rivals' innovation matter? A competitive dynamics perspective on firms' product strategy. Journal of Business Research, 76(9), 1-7.

Cheng, C. C., \& Krumwiede, D. (2012). The role of service innovation in the market orientation: New service performance linkage. Technovation, 32(8), 487-497.

Chukwuemeka, O. W., \& Onuoha, B. C. (2018). Dynamic capabilities and competitive advantage of fast foods restaurants. International Journal of Management Science and Business Administration, 4(3), 7-14.

Cummings, T. G., \& Worley, C. G. (2015). Organisation development and change. Stamford: Cengage Learning.

Dirisu, J. I., Iyiola, O. O S. Ibidunni (2013). Product differentiation: A tool of competitive advantage and optimal organisational performance: A study of Unilever Nigeria Plc. European Scientific Journal, 9(34), 43-60.

Fang, E. (2008). Customer participation and the trade-off between new product innovativeness and speed to market. Journal of Marketing, 72(4), 90-104.

Feng, T., Huang, Y., \& Avgerinos, E. (2018). When marketing and manufacturing departments integrate: The influences of market newness and competitive intensity. Industrial Marketing Management, 75(9), 218-231.

Feng-Jyh, L., \& Ching-Wei, H. (2019). The knowledge of entry mode decision for small and medium enterprises. Journal of Innovation \& Knowledge, 4(1), 32-37.

Fidel, P., Schlesinger, W., \& Cervera, A. (2015). Collaborating to innovate: Effects on customer knowledge management and performance. Journal of Business Research, 68(7), 1426-1428.

Foroudi, P., Jin, Z., Gupta, S., Melewar, T., \& Foroudi, M. M. (2016). Influence of innovation capability and customer experience on reputation and loyalty. Journal of Business Research, 69(11), 4882-4889.

Gumusluoglu, L., \& Acur, N. (2016). Fit among business strategy, strategy formality, and dynamic capability cevelopment in new product development. European Management Review, 13(2), 107-123.

Gurianova, E., \& Mechtcheriakova, S. (2015). Design of organisational structures of management according to strategy of development of the enterprises. Procedia Economics and Finance, 24(5), 395-401.

Gustafsson, A., Kristensson, P., \& Witell, L. (2012). Customer co- creation in service innovation: A matter of communication? Journal of Service Management, 23(3), 311-327.

Ha, H., \& Perks, H. (2005). Effects of consumer perceptions of brand experience on the web: Brand familiarity, satisfaction and brand trust. Journal of Consumer Behaviour, 4(6), 438-452.

Hair, J. F., Black, W. C., Babin, B. J., \& Anderson, R. E. (2018), Multivariate data analysis, 8th ed.. Andover, Hampshire: Cengage Learning, EMEA.

Idowu, A. (2013). Organisational learning, innovativeness and financial performance of small and medium enterprises (SMEs) in Nigeria. European Journal of Business and Management, 5(2), 179-186.

Kadic-Maglajlic, S., Boso, N., \& Micevski, M. (2018). How internal marketing drive customer satisfaction in matured and maturing European markets? Journal of Business Research, 86(11), 291-299.

Kaur, V., \& Mehta, V. (2017). Dynamic capabilities for competitive advantage: A comparative study of IT multinationals in India. Paradigm, 21(1) 31-51.

Khan, I., Garg, R. J., \& Rahman, Z. (2015). Customer service experience in hotel operations: An empirical analysis. Procedia - Social and Behavioural Sciences, 189(3), 266-274.

Kim, H., Chua, B., Lee, S., Boo, H., \& Han, H. (2015). Understanding airline travelers' perceptions of well-being: The role of cognition, emotion, and sensory experiences in airline lounges. Journal of Travel \& Tourism Marketing, 33(9), 1213-1234.

Lee, R., Lee, J., \& Garrett, T. C. (2017). Synergy effects of innovation on firm performance. Journal of Business Research, Journal of Business Research, 69(4), 677-684.

Lee, P., Wu, M., Kuo, C., \& Li, C. J. (2016). How to deploy multiunit organisations' dynamic 
capabilities? Management Decision, 54(4), 965-980.

Lin, Y. H. (2015). Innovative brand experience's influence on brand equity and brand satisfaction. Journal of Business Research, 68(11), 2254-2259.

McCann, B. T., \& Bahl, M. (2016). The influence of competition from informal firms on new product development. Strategic Management Journal, 38(7), 1518-1535.

Mu, J., Bao, Y., Sekhon, T., Qi, J., \& Love, E. (2018). Outside-in marketing capability and firm performance. Industrial Marketing Management, 75(6), 37-54.

Mu, J., Thomas, E., Peng, G., \& Di Benedetto, A. (2017). Strategic orientation and new product development performance: The role of networking capability and networking ability. Industrial Marketing Management, 64(8), 187-201.

Mu, J. (2015). Marketing capability, organisational adaptation and new product development performance. Industrial Marketing Management, 49(7), 151-166.

Mu, J. (2017). Dynamic capability and firm performance: The role of marketing capability and operations capability. IEEE Transactions on Engineering Management, 64(4), 554-565.

Nairametrics (2018). Stiff competition shuts down Procter \& Gamble 's \$300m diapers plant [Web log post]. Retrieved from https://nairametrics.com/stiff-competition-shuts-down-pgs-300mdiapers-plant/

Nairametrics (2017). Baby-care industry in Nigeria [Web log post]. Retrieved from https://nairametrics.com/stiff-competition-in-Baby-care-industry/

Najafi-Tavani, S., Najafi-Tavani, Z., Naudé, P., Oghazi, P., \& Zeynaloo, E. (2018). How collaborative innovation networks affect NPP: Product innovation capability, process innovation capability, and absorptive capacity. Industrial Marketing Management, 73(4), 193-205.

Namusonge, G. S., Muturi, W., \& Olaniran, O. (2016). The role of innovation on performance of firms on Nigerian stock exchange. European Journal of Research and Reflection in Management Sciences, 4(1), 101-118.

Ngo, L. V., Bucic, T., Sinha, A., \& Lu, V. N. (2019). Effective sense-and-respond strategies: Mediating roles of exploratory and exploitative innovation. Journal of Business Research, 94(2), 154161.

Ngo, L. V., \& O'Cass, A. (2012). In search of innovation and customer-related performance superiority: The role of market orientation, marketing capability, and innovation capability interactions. Journal of Product Innovation Management, 29(5), 861-877.

Ngo, L. V., \& O'Cass, A. (2013). Innovation and business success: The mediating role of customer participation. Journal of Business Research, 66(8), 1134-1142.

Nwonu, C. O., Agbaeze, E. K., \& Obi-Anike, H. O. (2017). Effect of organisational structure on performance of selected manufacturing companies in Enugu state Nigeria. The International Journal of Business \& Management, 5(5), 190-206.

Oliveira, J. S., Yazdani, N., Cadogan, J. W., Hodgkinson, I. R., Tsougkou, E., Jean, R., Boso, N. (2018). The empirical link between export entry-mode diversity and export performance: A contingency and institutional-based examination. Journal of Business Research, 88(6), 505512.

Onamusi, A. B. (2019). Moderating effect of customer engagement on new product development capability and NPP in Baby-diaper industry in Nigeria. The International Journal of Business \& Management, 7(12), 61-72.

Onamusi, A. B., Asikhia, O. U., \& Makinde, O. G. (2019). Environmental munificence and service firm performance: The moderating role of management innovation capability. Business Management Dynamics, 9(6), 13-25.

Procter \& Gamble. (2018) Press release on strategic options for Diaper production in Nigeria. Retrieved from P\&G Nigeria website: http://www.p\&gnigeria.ng.com

PZ Cusson Nig. Plc. (2019). Press release on decreasing exposure to the Nigeria market. Retrieved from PZ Cusson Nigeria website: http://www.pzcussons.ng.com

Sahin, A., Turhan, G., \& Zehir, C. (2013). Building behavioural intentions in automotive industry: Brand experience, satisfaction, trust, direct mail communication and attitudes toward 
advertising. Business Management Dynamics 3(4), 45-61.

Sayilar, Y. (2016). The past, present and future of structural contingency theory. International Business Review, 23(10), 1423-1437.

Schilke, O., Hu, S., \& Helfat, C. E. (2018). Quo Vadis, dynamic capabilities? A content-analytic review of the current state of knowledge and recommendations for future research. Academy of Management Annals, 12(1), 390-439.

Schoonhoven, C. B. (1981). Problems with contingency theory: Testing assumptions hidden within the language of contingency theory. Administrative Science Quarterly, 26(3), 349.

Shinkle, G. A., \& McCann, B. T. (2014). New product deployment: The moderating influence of economic institutional context. Strategic Management Journal, 35(7), 1090-1101.

Sok, P., \& O'Cass, A. (2015). Examining the new product innovation-performance relationship: Optimizing the role of individual-level creativity and attention-to-detail. Industrial Marketing Management, 47(5), 156-165.

Song, M., \& Chen, Y. (2014). Organisational attributes, market Growth, and product innovation. Journal of Product Innovation Management, 31(6), 1312-1329.

Sylva, W., Ofoegbu, C. W., \& Akpan, E. E. (2016). The impact of knowledge management on product innovation of manufacturing firms in Nigeria. Information and Knowledge Management, 6(6), $78-87$.

Talaja, A. (2013). Innovative capabilities, firm performance and foreign ownership: Empirical analysis of large and medium-sized companies form all industries. Business and Economic Horizons, 9(3), 69-78.

Teece, D. J. (2014a). A dynamic capabilities-based entrepreneurial theory of the multinational enterprise. Journal of International Business Studies, 45(1), 8-37.

Titus, V. K., \& Anderson, B. S. (2018). Firm structure and environment as contingencies to the corporate venture capital-parent firm value relationship. Entrepreneurship Theory and Practice, 42(3), 498-522.

Tsai, K., \& Hsu, T. T. (2014). Cross-functional collaboration, competitive intensity, knowledge integration mechanisms, and NPP: A mediated moderation model. Industrial Marketing Management, 43(2), 293-303.

Tuan, N., Nhan, N., Giang, P., \& Ngoc, N. (2016). The effects of innovation on firm performance of supporting industries in Hanoi, Vietnam. Journal of Industrial Engineering and Management, 9(2), 413-426.

Ukpabio, M. G., Oyebisi, T. O., \& Siyanbola, W.O., (2017). Technological innovation and performance of manufacturing firms in Nigeria. International Journal of Innovative Research and Advanced Studies, 4(11), 201-217.

Vanpoucke, E., Vereecke, A., \& Wetzels, M. (2014). Developing supplier integration capabilities for sustainable competitive advantage: A dynamic capabilities approach. Journal of Operations Management, 32(7-8), 446-461.

Wang, C. L., Senaratne, C., \& Rafiq, M. (2015). Success traps, dynamic capabilities and firm performance. British Journal of Management, 26(1), 26-44.

Wei, Z., Yi, Y., \& Guo, H. (2014). Organisational learning ambidexterity, strategic flexibility, and new product development. Journal of Product Innovation Management, 31(4), 832-847.

Wilden, R., Gudergan, S. P., Nielsen, B. B., \& Lings, I. (2013). Dynamic capabilities and performance: Strategy, structure and environment. Long Range Planning, 46(1-2), 72-96.

Zahra, S. A., \& Covin, J. G. (1995). Contextual influences on the corporate entrepreneurshipperformance relationship: A longitudinal analysis. Journal of Business Venturing, 10(1), 4358.

Zhang, M., \& Hartley, J. L. (2018). Guanxi, IT systems, and innovation capability: The moderating role of proactiveness. Journal of Business Research, 90(5), 75-86. 